\title{
Aromatase activity in individual Day-11 pig blastocysts
}

\author{
J. van der Meulen, G. te Kronnie*, R. van Deursen and J. Geelen $\dagger$
}

Department of Animal Physiology, Agricultural University, Haarweg 10,6709 PJ Wageningen, The Netherlands; * Department of Experimental Animal Morphology and Cell Biology, Agricultural University, Marijkeweg 40,6709 PG Wageningen, The Netherlands; and †Organon International BV, Scientific Development Group, P.O. Box 20, 5340 BH Oss, The Netherlands

\begin{abstract}
Summary. Blastocysts were flushed from both uterine horns of 10 gilts on Day 11 of pregnancy. In these gilts $15 \cdot 1 \pm 2 \cdot 3$ (mean \pm s.d.) corpora lutea were present and $12 \cdot 7 \pm 3 \cdot 1$ spherical blastocysts were recovered. In all the gilts variation in blastocyst diameter was observed. Aromatase activity was measurable in 118 of 121 examined blastocysts and varied from 0.005 to $19.330 \mathrm{pmol}\left[1 \beta-{ }^{3} \mathrm{H}\right]$ androstenedione converted into ${ }^{3} \mathrm{H}_{2} \mathrm{O}$ in $20 \mathrm{~min}$ (mean 1.31). This variation in aromatase activity reflected a difference between and within gilts. Of the total variation between all blastocysts, $67 \%$ was due to differences between gilts. A positive exponential relationship existed between blastocyst diameter and aromatase activity, but this relationship was different between gilts $(P<0.0001)$. The observed variation in aromatase activity may be caused by differences in germ layer differentiation of the blastocysts.
\end{abstract}

Keywords: pig; blastocyst; diameter; aromatase

\section{Introduction}

In the pig oestrogens appear to be responsible for the maternal recognition of pregnancy (Bazer \& Thatcher, 1977; Bazer et al., 1984). During the period of maternal recognition of pregnancy, oestrogens increase the blood flow (Ford et al., 1982) and change the uterine environment by stimulating the release of secretory material from the uterine glandular epithelium (Geisert et al., 1982). The synthesis of oestrogens is already measurable in pooled spherical Day 11-12 blastocysts with an average diameter of 5-7 mm (Perry et al., 1976; Fischer et al., 1985; Mondschein et al., 1985).

Amongst the blastocysts of one litter a considerable variation in diameter can exist on Day 11 of pregnancy (Anderson, 1978; Stroband et al., 1984). Pope et al. (1982) suggested that the larger blastocysts of such a litter may have a better chance for survival. Such blastocysts are morphologically more developed and their advanced synthesis of oestrogens may alter the uterine environment in such a way that their less developed littermates can no longer survive (Pope et al., 1982; Pope \& First, 1985). Advancing the uterine environment of pregnant gilts on Day 11 by administration of oestradiol valerate on Days 9-10 results in pregnancy failure in about $50 \%$ of the treated gilts on Day 16 or 30 (Pope et al., 1986; Morgan et al., 1987). An advanced uterine environment beyond Day 11 did not affect the pregnancy rate (Pope et al., 1986).

The survival of just some of the blastocysts within a litter may be caused by a difference in time of onset of oestrogen release or by the amount of oestrogen released by individual blastocysts of the litter. Although variation in blastocyst diameter within litters has been described (Anderson, 1978; Stroband et al., 1984), nothing is known about the aromatase activity of individual blastocysts. In this study the aromatase activity of individual Day- 11 blastocysts was investigated. The variation in aromatase activity within and between gilts was determined and correlated with variation in blastocyst diameter. 


\section{Materials and Methods}

Animals. Crossbred gilts (Great Yorkshire $\times$ Dutch Landrace) were checked for oestrus with a vasectomized boar twice daily $(08: 00$ and 16:00 h). They were artificially inseminated on Day $1,24 \mathrm{~h}$ after the time of observing first standing oestrus (Day 0). On Day 11 of pregnancy the 10 gilts were slaughtered. The blastocysts were recovered within $10 \mathrm{~min}$ after death by flushing both uterine horns twice with $30 \mathrm{ml}$ Dulbecco's phosphate-buffered saline (PBS, Gibco, Paisley, UK). The diameters of the blastocysts were measured and the blastocysts were rinsed in Dulbecco's PBS supplemented with dithiothreitol $(5 \mathrm{mg} / 1$ : Sigma, St Louis, MO, USA). The blastocysts were individually frozen in $100 \mu \mathrm{l}$ of the last rinsing buffer within $20 \mathrm{~min}$ after slaughter and stored at $-80^{\circ} \mathrm{C}$ until analysis.

Chemicals. $\left[1 \beta^{-3} \mathrm{H}\right]$ Androstenedione and $E n^{3}$ Hance scintillation spray were purchased from Du Pont de Nemours, Dreieich, FRG; glucose 6-phosphate, glucose 6-phosphate dehydrogenase and NADP from Boehringer, Mannheim, FRG; EDTA from Baker, Deventer, The Netherlands; BSA from Sigma, St Louis, MO, USA; Dextran T70 from Pharmacia, Uppsala, Sweden; and Norit A and precoated silica gel HF 254 thin-layer plates from Merck, Darmstadt, FRG. Liquid scintillation counting of tritium was done with picofluor-30 (Packard Instrument BV, Groningen, The Netherlands) in a 2200 CA-Tri-CARB liquid scintillation analyser (Packard Instrument Company, Downers Grove, IL, USA.

Aromatase assay. Aromatase activity was determined by measuring the amount of ${ }^{3} \mathrm{H}_{2} \mathrm{O}$ released from $\left[1 \beta-{ }^{3} \mathrm{H}\right]-$ androstenedione, according to the procedure of Thompson \& Siiteri (1974). The blastocysts were homogenized in an all-glass pestle in potassium phosphate buffer ( $10 \mathrm{~mm}, 1 \mathrm{~mm}$ EDTA, $1 \mathrm{~g} \mathrm{BSA} / 1, \mathrm{pH} 7 \cdot 4)$. The blastocyst homogenate was incubated with $\left[1 \beta-{ }^{3} \mathrm{H}\right]$ androstenedione (sp. act. $1.036 \mathrm{TBq} / \mathrm{mmol}, 90.4 \mathrm{pmol}$ ) and an NADPH-generating system (2.5 mM-NADP, 5.0 mM-glucose 6-phosphate, 525 units glucose 6-phosphate dehydrogenase/1). The reaction was allowed to proceed in air in a shaking water bath for $20 \mathrm{~min}$ at $37^{\circ} \mathrm{C}$, and terminated by addition of chloroform $(5 \mathrm{ml})$ and thorough mixing. After centrifugation $\left(15000 \mathrm{~g}, 10 \mathrm{~min}, 20^{\circ} \mathrm{C}\right)$ an aliquant of the aqueous phase $(1.8 \mathrm{ml})$ was mixed with $0.2 \%$ of a trichloroacetic acid solution $\left(300 \mathrm{~g} / \mathrm{l}\right.$ distilled water) and centrifuged $\left(15000 \mathrm{~g}, 5 \mathrm{~min}, 20^{\circ} \mathrm{C}\right)$. A part of the supernatant $(1 \mathrm{ml})$ was mixed with an equal volume of Dextran-coated charcoal suspension $(50 \mathrm{~g}$ Norit $\mathrm{A}$ and $5 \mathrm{~g}$ Dextran $\mathrm{T} 70 / 1$ distilled water) and centrifuged $\left(15000 \mathrm{~g}, 10 \mathrm{~min}, 20^{\circ} \mathrm{C}\right)$. Then $1.0 \mathrm{ml}$ supernatant was transferred to scintillation vials, $4 \mathrm{ml}$ picofluor- 30 were added and ${ }^{3} \mathrm{H}_{2} \mathrm{O}$ was counted. A part of the chloroform fraction $(2.5 \mathrm{ml})$ together with $0.2 \mathrm{mg}$ androstenedione and testosterone was evaporated under a stream of nitrogen at $45^{\circ} \mathrm{C}$. The residue was dissolved in $200 \mu \mathrm{l}$ ethanol and a part of this solution was applied to a thin-layer plate. This plate was developed in chloroform-ethylacetate ( $4: 1 \mathrm{v} / \mathrm{v}$, unsaturated chamber), dried, and after spraying with $\mathrm{En}^{3} \mathrm{Hance}$ spray it was stored with X-Omat RP Film (Kodak, France) at $-70^{\circ} \mathrm{C}$ for several days. After developing the film it could be checked whether the amount of $\left[1 \beta-{ }^{3} \mathrm{H}\right]$ androstenedione used had been restrictive for oestrogen production. The intra- and inter-assay coefficients of variation were $1.5 \%$ and $7.6 \%$, respectively. The aromatase activity is expressed as the amount of $\left[1 \beta-{ }^{3} \mathrm{H}\right]$ androstenedione converted into ${ }^{3} \mathrm{H}_{2} \mathrm{O}$ in $20 \mathrm{~min}$.

Statistical analysis. The aromatase activity was $\ln$ transformed and within-litter regression on diameter was performed using the General Linear Models procedure of the Statistical Analysis System (SAS Institute Inc., 1985). Differences in average blastocyst diameter and average aromatase activity between the uterine horns of individual gilts were tested for significance by Students' $t$ test. Data are expressed as mean \pm s.d.

\section{Results}

In the 10 gilts an average of $15 \cdot 1 \pm 2 \cdot 3$ (range 11-19) corpora lutea (CL) were present. The number of blastocysts recovered ranged from 5 to 16 (average $12 \cdot 7 \pm 3 \cdot 1$ ). In one gilt (No. 182) the recovery was less than $50 \%$, but in the other gilts the average recovery was $86.7 \%$ (Table 1 ). All the blastocysts recovered were spherical. In all the gilts variation in blastocyst diameter existed. The average difference in diameter between the smallest and largest blastocyst within a litter was $3 \mathrm{~mm}$, and ranged from $1 \mathrm{~mm}$ (Gilt 176) to $7 \mathrm{~mm}$ (Gilt 121). In 4 gilts there was a significant difference in average diameter between the blastocysts of the left and right uterine horn (Table 1).

Aromatase activity was measurable in all but 3 Day-11 blastocysts (average $1.31 \mathrm{pmol} /$ blastocyst $/ 20 \mathrm{~min}$; range $0 \cdot 005-19 \cdot 33$ ). Fluorographs from thin-layer chromatography showed, for all blastocysts in which aromatase activity was assessed, that the amount of $\left[1 \beta-{ }^{3} \mathrm{H}\right]$ androstenedione added to the reaction medium had not been limiting. Aromatase activity varied between and within gilts: of the total variation between all blastocysts, $67 \%$ was due to differences between gilts. Within gilts aromatase activity was different for blastocysts with the same diameter (Tables $1 \& 2$, e.g. Gilts 815 and 176), and blastocysts with the same aromatase activity differed in diameter (Tables $1 \& 2$, e.g. Gilts 282 and 33). In 2 gilts there was a significant difference in average aromatase activity between the blastocysts of the 2 uterine horns (Table 2). 
Aromatase activity in Day-11 pig blastocysts

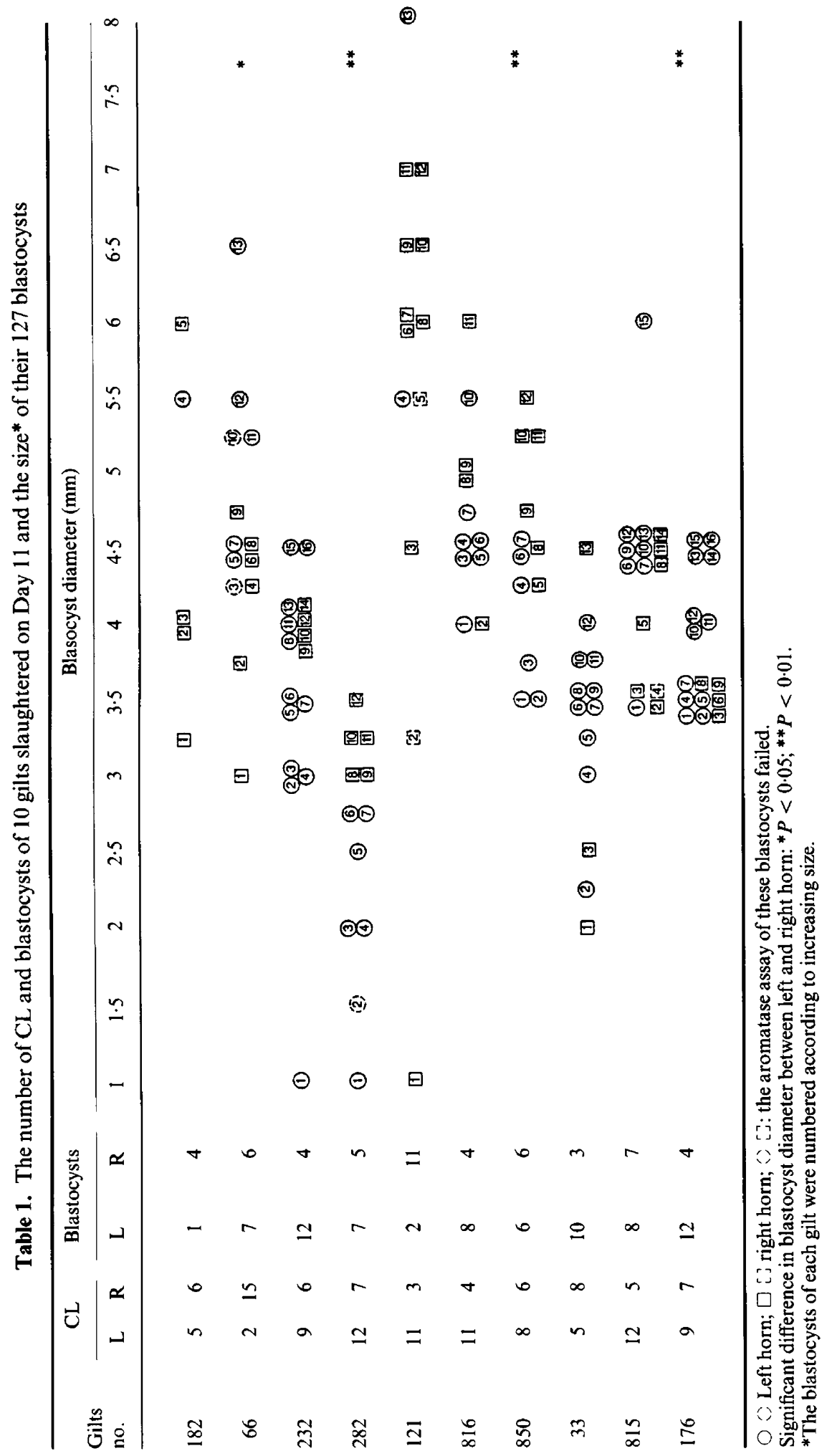




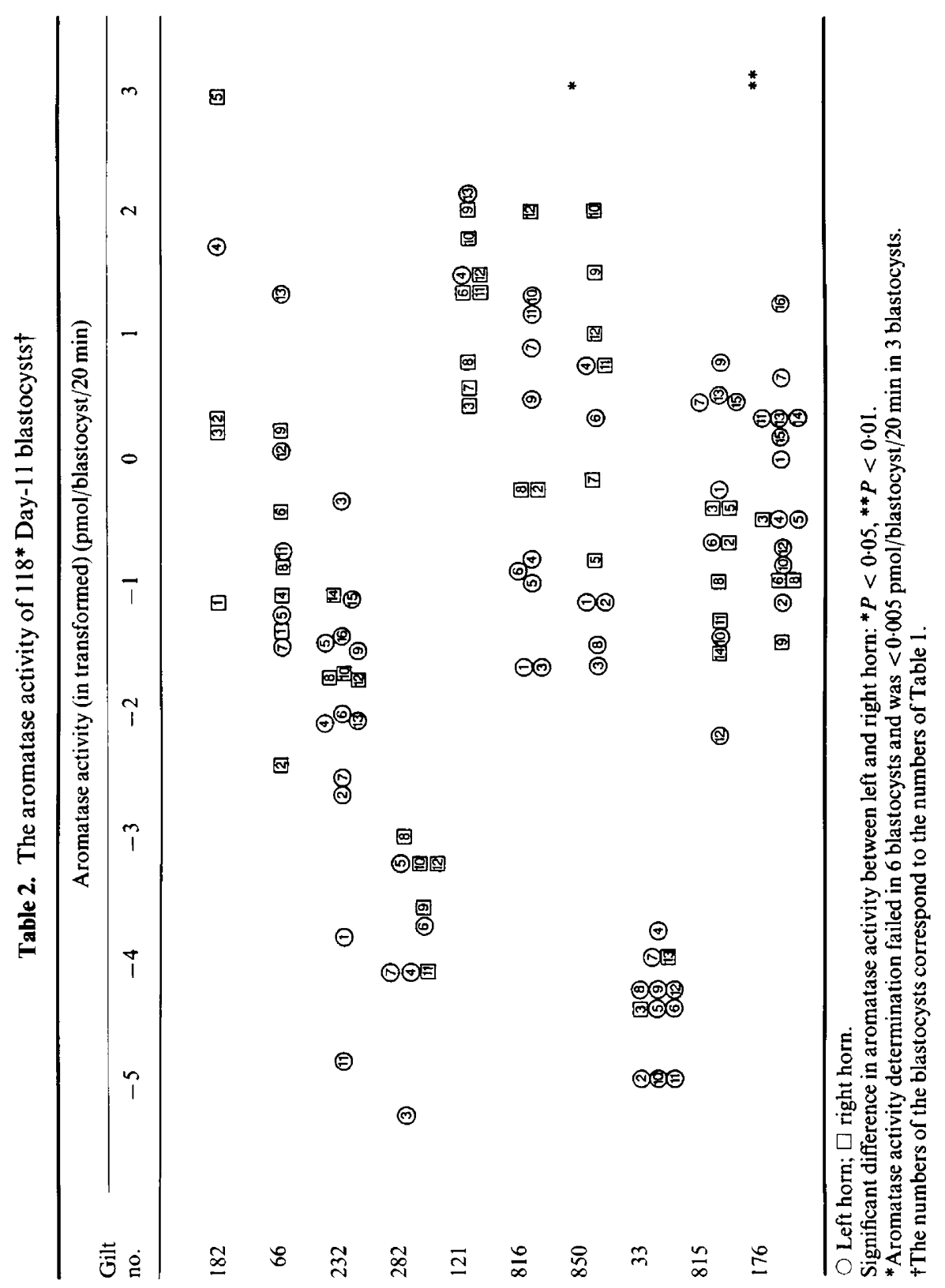


The relationship between aromatase activity and diameter within litters was significantly different for the 10 gilts $\left(\mathrm{R}^{2}=0.88, P<0.0001\right)$ (Fig. 1). Even between gilts with almost the same range in blastocyst diameter a large difference in aromatase activity was present (Fig. 1, Gilts 850 and 815 ).

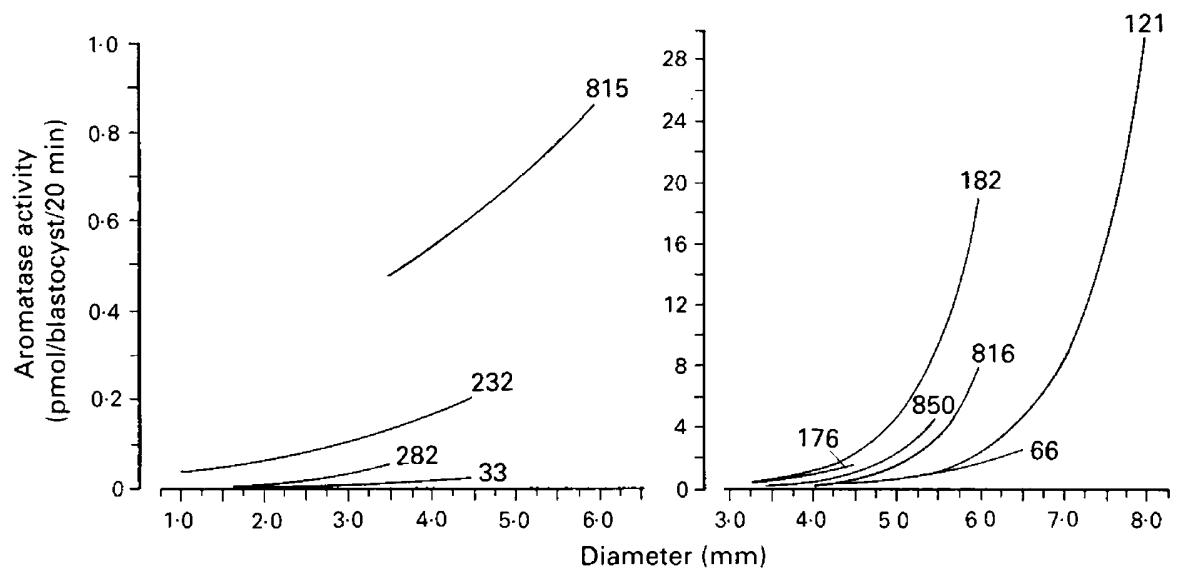

Fig 1. The relationship between aromatase activity and blastocyst diameter in the 10 gilts (indicated by the no. given).

\section{Discussion}

For the first time the aromatase activity of individual spherical pig blastocysts has been measured. All but 3 of 121 blastocysts examined from 10 gilts on Day 11 of pregnancy showed aromatase activity, varying from 0.005 to $19.33 \mathrm{pmol} /$ blastocyst $/ 20 \mathrm{~min}$. This reflects a variation between gilts ( $67 \%$ of the total variation), as well as a variation within gilts ( $33 \%$ of the total variation).

Assuming that differences in aromatase activity reflect differences in developmental stage among the blastocysts it could be an important functional marker to quantitate developmental variation. A commonly used measure to describe variation in blastocyst development in pigs is the diameter of the spherical blastocyst. The results of this study confirm the presence of variation in Day-1 1 blastocyst diameter (Anderson, 1978; Stroband et al., 1984). An increase in average blastocyst diameter results in an increase in oestrogen content in uterine flushing from Day 10.5 to 12 (Geisert et al., 1982) and an increase in aromatase activity in vitro from Day 10 to 13 (Mondschein et al., 1985). The results of this study show that aromatase activity of individual blastocysts differs. On average the aromatase activity of larger blastocysts is higher than in smaller blastocysts; a positive exponential relationship between blastocyst diameter and aromatase activity was observed. Aromatase activity of blastocysts of virtually the same diameter, however, can be different. Embryoblasts of Day-11 blastocysts with nearly the same diameter may also differ greatly in cell number (te Kronnie et al., 1988). Apparently diameter and aromatase activity or embryoblast cell number do not give the same information about developmental stage.

On Day 10 oestrone has been demonstrated in trophoblast cells (King \& Ackerley, 1985), and from Day 12 oestrone and oestradiol-17 $\beta$ are not only present in trophoblast cells, but also in large quantity in the hypoblast (King \& Ackerley, 1985; Bate \& King, 1988). The presence from Day 11 onwards of mitochondria resembling those in steroid-producing cells indicates that the ability to synthesize oestrogen is present, not only in trophoblast and hypoblast, but also in embryoblast cells (Stroband et al., 1984). This suggests that aromatase activity depends on the degree of germ layer differentiation. A different degree of germ layer differentiation between blastocysts of the same age may therefore account for the observed difference in aromatase activity between blastocysts of the same age and diameter. 
Developmental variation between Day-11 blastocysts may be caused by differences between gilts in the moment of ovulation during oestrus (Stroband et al., 1984; Helmond et al., 1986) and differences in the duration of ovulation (Elze et al., 1987). A genetic paternal influence which has been found in pigs has been suggested as another source of difference in oestrogen production between litters (L. A. Bate \& R. R. Hacker, unpublished data, quoted by Bate \& King, 1988).

The results of this study, with regard to the existence of differences in aromatase activity between individual blastocysts within a uterus, support the hypothesis of Pope et al. (1982). To what extent this results in an altered local uterine environment, detrimental for some blastocysts, remains to be investigated. It will be necessary to study the degree of differences in aromatase activity between individual blastocysts and the distribution of the blastocysts within the uterine horns.

We thank Dr T. van der Lende for advice and assistance in statistical analysis; and Mr K. Boekhorst for preparation of the illustrations. This work was carried out as a project of the Research Group on Early Pregnancy of the Agricultural University.

\section{References}

Anderson, L.L. (1978) Growth, protein content and distribution of early pig embryos. Anat. Rec. 190, 143-154.

Bate, L.A. \& King, G.J. (1988) Production of oestrone and oestradiol- $17 \beta$ by different regions of the filamentous pig blastocyst. $J$. Reprod. Fert. 84, 163-169.

Bazer, F.W. \& Thatcher, W.W. (1977) Theory of maternal recognition of pregnancy in swine based on estrogen controlled endocrine versus exocrine secretion of prostaglandin $\mathrm{F}_{2 \alpha}$ by the uterine endometrium. Prostaglandins 14, 397-401.

Bazer, F.W., Marengo, S.R., Geisert, R.D. \& Thatcher, W.W. (1984) Exocrine versus endocrine secretion of prostaglandin $F_{2 \alpha}$ in the control of pregnancy in swine. Anim. Reprod. Sci. 7, 115-132.

Elze, K., Jacob, D., Uecker, B. \& Richter, P. (1987) Verlauf der Blastogenese in Bezug auf die embryonale Mortalität beim Schwein. Mh. Vet. Med. 42 , 543-545.

Fischer, H.E., Bazer, F.W. \& Fields, M.J. (1985) Steroid metabolism by endometrial and conceptus tissues during early pregnancy and pseudopregnancy in gilts. J. Reprod. Fert. 75, 69-78.

Ford, S.P., Christenson, R.K. \& Ford, J.J. (1982) Uterine blood flow and uterine arterial, venous and luminal concentrations of oestrogens on Days 11, 13 and 15 after oestrus in pregnant and non-pregnant sows. $J$. Reprod. Fert. 64, 185-190.

Geisert, R.D., Renegar, R.H., Thatcher, W.W., Roberts, R.M. \& Bazer, F.W. (1982) Establishment of pregnancy in the pig. I. Interrelationships between preimplantation development of the pig blastocyst and uterine endometrial secretions. Biol. Reprod. 27, 925-939.

Helmond, F., Aarnink, A. \& Oudenaarden, C. (1986) Periovulatory hormone profiles in relation to embryonic development and mortality in pigs. In Embryonic Mortality in Farm Animals, pp. 119-125. Eds J. M. Sreenan \& M. G. Diskin. Martinus Nijhoff, Dordrecht.

King, G.J. \& Ackerley, C.A. (1985) Demonstration of oestrogens in developing pig trophectoderm and yolk sac endoderm between Days 10 and 16. J. Reprod. Fert. 73, 361-367.

Mondschein, J.S., Hersey, R.M., Dey, S.K., Davis, D.L. \& Weisz, J. (1985) Catechol estrogen formation by pig blastocysts during the preimplantation period: biochemical characterization of estrogen-2/4-hydroxylase and correlation with aromatase activity. Endocrinology 117, 2339-2346.

Morgan, G.L., Geisert, R.D., Zavy, M.T. \& Fazleabas, A.T. (1987) Development and survival of pig blastocysts after oestrogen administration on Day 9 or Days 9 and 10 of pregnancy. J. Reprod. Fert. 80, 133-141.

Perry, J.S., Heap, R.B., Burton, R.D. \& Gadsby, J.E. (1976) Endocrinology of the blastocyst and its role in the establishment of pregnancy. J. Reprod. Fert., Suppl. 25, 85-104.

Pope, W.F. \& First, N.L. (1985) Factors affecting the survival of pig embryos. Theriogenology 23, 91-105.

Pope, W.F., Maurer, R.R. \& Stormshak, F. (1982) Survival of porcine embryos after asynchronous transfer. Proc. Soc. exp. Biol. Med. 171, 179-183.

Pope, W.F., Lawyer, M.S., Butler, W.R., Foote, R.H. \& First, N.L. (1986) Dose-response shift in the ability of gilts to remain pregnant following exogenous estradiol-17ß exposure. J. Anim. Sci. 63, 1208-1210.

SAS Institute Inc. (1985) SAS User's Guide: Statistics. SAS Institute, Inc., Cary.

Stroband, H.W.J., Taverne, N. \& van der Bogaard, M. (1984) The pig blastocyst: its ultrastructure and uptake of protein macromolecules. Cell Tissue Res. 235, 347-356.

te Kronnie, G., Boerjan, M.L. \& Leen, T. (1988) The relation between trophoblast and embryoblast size of day 11 pig conceptus. J. Reprod. Fert., Abstr. Ser. 1, 59 , abstr.

Thompson, E.A. \& Sitteri, P.K. (1974) Utilization of oxygen and reduced nicotinamide adenine dinucleotide phosphate by human placental microsomes during aromatization of androstenedione. J. biol. Chem. 249, 5364-5372.

Received 5 April 1989 